STUDI

FRANCESI

\section{Studi Francesi}

Rivista quadrimestrale fondata da Franco Simone

194 (LXV | II) | 2021

Baudelaire et son cénacle

\title{
LAURA RAMELLO, La scrittura autobiografica nel "Livre du Chevalier errant" di Tommaso III di Saluzzo
}

\author{
Maria Colombo Timelli
}

\section{OpenEdition}

\section{Journals}

Édition électronique

URL : https://journals.openedition.org/studifrancesi/44729

DOI : $10.4000 /$ studifrancesi.44729

ISSN : 2427-5856

Éditeur

Rosenberg \& Sellier

Édition imprimée

Date de publication : 1 août 2021

Pagination : 351

ISSN : 0039-2944

Référence électronique

Maria Colombo Timelli, " LaURA Ramello, La scrittura autobiografica nel "Livre du Chevalier errant" di

Tommaso III di Saluzzo », Studi Francesi [En ligne], 194 (LXV | II) | 2021, mis en ligne le 06 septembre 2021, consulté le 15 octobre 2022. URL : http://journals.openedition.org/studifrancesi/44729 ; DOI : https://doi.org/10.4000/studifrancesi.44729

Ce document a été généré automatiquement le 15 octobre 2022

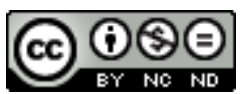

Creative Commons - Attribution - Pas d'Utilisation Commerciale - Pas de Modification 4.0 International - CC BY-NC-ND 4.0

https://creativecommons.org/licenses/by-nc-nd/4.0/ 


\title{
LAURA RAMELLO, La scrittura autobiografica nel "Livre du Chevalier errant" di Tommaso III di Saluzzo
}

\author{
Maria Colombo Timelli
}

\section{RÉFÉRENCE}

LAURA RAMELLO, La scrittura autobiografica nel "Livre du Chevalier errant" di Tommaso III di Saluzzo, in Studi sulla Letteratura Cavalleresca in Francia e in Italia (secoli xiii-xvi), Volume III, a cura di M. Lecco, Alessandria, Edizioni dell'Orso, 2020, pp. 113-140.

1 Ce long article essaie de montrer comment et dans quelle mesure le Livre du Chevalier errant de Thomas III de Saluce peut être lu comme une œuvre autobiographique. Les éléments pris en compte sont nombreux: évocation explicite de membres de son propre lignage, d'événements et de personnages historiques, voire de situations politiques contemporaines. Sur le plan littéraire, L.R. souligne aussi les éléments qui rapprochent le Chevalier errant du corpus des «biographies chevaleresques» étudiées par Élisabeth Gaucher; mais surtout, elle souligne la double écriture qui caractérise cette œuvre unique, à savoir une écriture engagée, politique, transmise par le manuscrit parisien, et une écriture plus personnelle, réalisée dans le manuscrit turinois. 